\title{
For Body, Mind and the Nation: An Archaeology of Modern Japanese Psychiatry
}

\author{
Bernhard Leitner
}

\begin{abstract}
This paper reassesses the history of psychiatry in Japan through application of the theory of disciplinary power by Michel Foucault. The society of the early Meiji era (1868-1912) is defined as a disciplinary society within the scope of discourses on punishment and general social reforms. By focussing on a close reading of both canonical and marginalised fragments of psychiatric texts, this analysis reveals their constitutive character for the establishment of psychiatric discourses. These texts, rooted in biological psychiatry, are shown to stress the hazard that mental illness presented to the nation. Recourse to juridical problems, which derive from enacting a European model of law, provides an explanation for the necessity of psychiatry as a social institution. The key point is to identify a discursive break between two major legal acts dealing with the confinement of the mentally ill: the Mental Patients Custody Act of 1900 and the Mental Hospital Act of 1919. The first deals mainly with administrative issues, while the latter was formed under the influence of an emerging psychiatric power. The Mental Hospital Act refines the disciplinary network operating in the social space, while blurring the discursive fissure between traditional care and psychiatric techniques.
\end{abstract}

Keywords: psychiatry, Japan, Meiji era, Kure Shūzō, Emil Kraepelin Japanese Psychiatry." In Vienna Journal of East Asian Studies, Volume 5, eds. 


\section{Introduction}

At what point in the history of Japan did mental illness turn into a silent phenomenon, so that the mentally ill are not spoken to, but spoken about? Since when did Japanese discourse think about mental illness in terms of a mere pathological state, rather than, for example, a magic-religious experience? Which discursive setting nurtured the genesis of psychiatry in Japan? Which discourses were necessary for the instalment of a Western medical method in opposition to classical Chinese medicine, then predominant? How, for example, did jurisprudence intervene for the benefit of psychiatry? What necessary conflicts derived from the collision of modern psychiatry with traditional forms of care for the mentally ill? This paper tries to answer these questions in the broader framework of the rise of psychiatry from the onset of the Meiji era to its establishment as a scientific social actor in the early 20th century.

Psychiatry first entered the public stage of Japanese discourse as a central scientific authority in the year 1919 through the enactment of the Seishinbyōin-hō 精神病 院法, the Mental Hospital Act. For the first time in Japanese history, this law officially turned the diagnosis and treatment of mental illness into objects of medical gaze, rather than a religious practice - although 19 years before, in 1900, a law to codify treatment of the mentally ill called the Seishinbyōsha-kango-hō 精神病者監 護法, the Mental Patients Custody Act, had already been passed. In the present paper I want to show that these two laws, even though they both deal with the same subject of the treatment of mental patients in a relatively short period of time, follow a completely different logical framework and that they are in fact divided by a discursive break. Whereas the law of 1900 was established within the paradigm of sovereign power concerned with public peace through administrative engineering, the law of 1919 represents the intervention of a medical-disciplinary form of power, which constantly has to enclose the insane subject in order to assess the threat of its invisible disease. Extensive medical observation in a psychiatric institution is legitimised in terms of a risk management for the social body, but simultaneously installs a highly effective system of disciplinary regulation. In this sense, psychiatry establishes the paradigmatic arrangement of a disciplinary society.

In 1918, the father of modern Japanese psychiatry, Kure Shūzō 只秀三, published the results of an influential field study entitled Seishinbyōsha shitakukanchi no jikkyō oyobi sono tōkeiteki kansatsu 精神病者私宅監置ノ実況及ビ其統計的観 察 (The Situation of Private Custody of the Insane and its Statistical Survey) (Kure and Kashida 2009 [1918]). With this publication, Kure called for a psychiatric lobby to fulfil the task of rapidly setting up psychiatric institutions throughout the country. But this task of building a network of asylums and hospitals on the European pattern, which had grown through several centuries, was not to be completed so soon. First of all, far fewer monetary resources were to hand and secondly, too much 
resistance was encountered among the population, especially in the countryside. Notwithstanding the considerable strength that the idea of disciplinary power had already acquired in Meiji Japan, observable through the reformation of the prison system and the rise of prison-like workhouses (Botsman 2005), it might be possible to present Japanese society of that time as disciplinary, but by no means disciplined, as Foucault might have put it (Foucault 2005: 20). Thus, the term 'disciplinary' should be understood as aiming at the implementation of discipline, but without determining that a disciplinary regime quintessentially succeeds in this task.

At this point, a whole set of questions arises: is it possible to render Japanese psychiatry as a disciplinary structure, and which specific techniques of power were deployed by psychiatric science to construct a disciplinary society in Japan? How did psychiatry manage to break with traditional forms of medical practice concerning the mentally ill, or in other words, how is it possible to grasp the discursive break enacted through this new psychiatric discourse? All the questions raised in this introduction culminate in one central question, the core of the present paper: how did Japanese psychiatry act as an agent in the production of a discursive break resulting in the transformation of a pre-modern Japanese society into a modern disciplinary society, and by what methods did it succeed?

These questions will be answered with a special emphasis on the period between the Meiji restoration around 1868 and the onset of World War II. The reasons for this historic bracketing are manifold: psychiatry, like the other specialised fields of Western-oriented medicine in Japan was not institutionalised comprehensively until the Meiji restoration. During World War II another complex discourse arises with crimes against patients through malnutrition and euthanasia programmes, which represents a topic worth an analysis on its own. And last but not least, the period after World War II opens a whole new chapter in the history of Japanese medicine, as medical sciences and institutions were restructured after US/American models. Naturally these brackets should be seen as rough guidelines and will be bypassed at times for the sake of the argument.

\section{Breaking into history}

For a long period the scientific account of the history of Japanese psychiatry was dealt with only from the perspective of psychiatry itself. There have been studies with an interest in the social dynamics of psychiatric impact on society, but mostly within medical disciplines. This becomes evident when one sees that the major part of the scientific output on the history of Japanese psychiatry can be found in medical journals like the American Journal of Psychiatry, History of Psychiatry, the Psychiatric Bulletin or the Japanese journal Seishin Shinkeigaku Zasshi 精神神経学雑誌 (Psychiatria et Neurologia Japonica). Eminent historians studying the history of 
psychiatry from the viewpoint of social sciences have also accounted for this deficiency; '...many...works have been written by practising psychiatrists, not by professional historians...' (Suzuki 2003b: 338). Another characteristic feature of the canonical texts of history of Japanese psychiatry is the line of demarcation between two diametrically opposed narratives. The first, represented by the works of Totsuka Etsurō, Kumasaka Yoshino and Yoshioka Shinji, engages in a fierce critique of the backwardness of Japanese psychiatry and its inhuman practices (see Totsuka 1990; Kumasaka and Yoshioka 1968), mirroring the common Western criticism of 20thcentury medicine (see Stieda 1906: 514-522). The second, 'nihonron-like' 日本論 narrative challenges these accusations by referring to genuine Japanese modes of psychiatric care in order to draw a more positive picture of early Japanese psychiatry (see Suzuki 2003a: 193-225; Nakatani 2003: 194-198). Juxtaposition of these dipolar currents allows a differentiated approach to the discourse, one that is neither chauvinistic, nor romantic.

The initial spark for a social history of Japanese psychiatry was unquestionably the work of Okada Yasuo 岡田靖雄, who laid the foundation for further research with his ground-breaking sociological analysis of a private mental hospital in Tōkyō 東京 (Suzuki 2003b: 337). He also edited the first publication of the collected writings of Kure Shūzō in the 1970s. The reissuing of the central texts of Kure beginning in the year 2000 may also be seen as a newly awakened interest in untouched episodes of the social history of Japanese psychiatry (Kure 2002; 2003a; 2003b; Kure and Kashida 2009). Generally speaking, the 21 st century gave birth to a quantity of new studies and material in the field. The sociologist Serizawa Kazuya 芹沢一也, for example, tried to reframe Japanese psychiatry in the context of a discourse analysis of medicine in the aftermath of Michel Foucault's impact on social sciences, which had not been applied to the study of psychiatry in Japan so far (Serizawa 2001; 2007). But his conceptions are focused on the postwar period or contemporary issues (see Serizawa 2005; 2006; 2007), meaning that a discourse analysis of Japanese psychiatry in the early modern period as proposed by the present paper is still missing. Although research on the social history of mental institutions (Kanekawa and Hori 2009), or on diverse topics such as rural modes of psychiatric care has been conducted (Hashimoto 2010a), these studies still lack detailed enquiries into the theoretical and textual framework of psychiatric discourse in Japan.

Recent scientific output on the history of Japanese psychiatry is not only concerned with Japanese-speaking areas, but even reaches a global scale. Two distinguished international publications are worth mentioning: The Confinement of the Insane: International Perspectives, 1800-1965 (2003), edited by the renowned medical historians Roy Porter and David Wright, which features a study on psychiatric care between 1900 and 1945, and Transnational Psychiatries: Social and Cultural Histories of Psychiatry in Comparative Perspective, c. 1800-2000 (Ernst 
and Mueller 2010), containing three contributions with topics ranging from depression to shock therapies and family care in Japan.

Following this short assessment of the research on Japanese psychiatry already available, I will now discuss my theoretical and methodological approach to further highlight the relevance of my own contribution to the field.

\section{History, power and society}

My methodological reflections draw on deficiencies in the 'canonical' texts on the history of Japanese psychiatry described above, in the sense that they grasp this history only in terms of historical narratives of continuous developments, be it from the dark ages of inhuman practice to modern psychiatry, or the constant development from genuine Japanese traditions to the level of a modern medical profession. On the other hand, I am not interested in reconstructing a consistent story of development or, in other words, following Alun Munslow's critique on historical methods, in constructing a new historical narrative (see Munslow 2006: 39-41). This is the reason why the present project is titled as archaeology, not history. What interests me most are the basic conditions possible for the emergence of psychiatric discourse, in order to observe the divides in the discursive landscape of early modern Japan. The genesis of a new discourse, the transmission of a discourse into a new environment or the mounting of a discourse under different circumstances needs conjunction and overlapping with other discourses. Analysing a discourse like psychiatry, which is connected to such diverse discourses as the law, state policy, industrial production, statistics and other medical fields therefore means analysing not a single discourse, but rather a whole discourse network (Foucault 2002: 30-31). These other discourses do not have to be essentially akin to the central discourse; however, in deconstructing the boundaries of the discursive network to the very centre of the discourse, it is possible to reveal the constitutive character of seemingly unrelated topics for the core of the discourse. Discourses tend to obscure these traces of 'alien' constituents and try to link themselves with the 'supplementary' ones only where it is absolutely necessary for legitimising their existence (Derrida 1997: 141164). In a careful, close reading of marginalised fragments of psychiatric texts from Japan and Europe, one is able to turn psychiatry's symptomatic kernel inside out, because, as the French philosopher Jacques Derrida most eloquently pointed out: on the inside of a discourse, contrary to expectations we encounter its outside (Derrida 1978: 353-354). At the same time we ought not to forget to recognise the uniqueness of the discourse: 'one has to show, why [the discourse] could only exist, as it had existed, in what sense it was exclusive compared to all the others, how it occupied its place in-between the others, a place no other could have occupied' (Foucault 2002: 30-31). 
My theoretical framework derives from the fact that even in recent literature on the history of Japanese psychiatry, a thorough discourse analysis of the textual corpus of significant Japanese psychiatrists and the outlines of their psychiatric scientific theories is still missing. I will therefore quickly elaborate on the theoretical assumptions of the present paper, before I am finally able to embark upon the actual analysis.

I shall begin with the apparently simple question: what is power? As it is very difficult to answer this question without a long treatise on the modes of power relations among individuals or in society, I am going to bypass this question by posing another question: what is a vector field? This question can be easily answered: a vector field is a function. It is composed by assigning a vector to every single point in a given space. A vector possesses a norm, its size or length, and a direction, in a word: a force. Power as I understand it can be seen as a vector field composed of the totality of directed forces of all processes in the social space. Every position has a vector, every process a force, all together affecting the power field. The point of this metaphor is: power is strictly imminent to all types of discourses operating in social space including public, popular and scientific ones (see Foucault 1978: 93-95). Relations of power are therefore not limited to results of individual action; the intention of an individual action or proposition becomes explicable only in terms of relations of power within a discursive space. Hence power and the production of knowledge are radically interwoven. Michel Foucault once famously pointed out '...that there is no power relation without the correlative constitution of a field of knowledge, nor any knowledge that does not presuppose and constitute at the same time power relations' (Foucault 1995: 27). Furthermore it is crucial to hold that there are different types of relations of power, as there are different types of physical vector fields like magnetic fields and gravitational fields. Two basic types of 'power fields', manifest, as we will see also, in their different accounts of the mentally ill, are sovereign power and disciplinary power.

The sovereign mode of power relations is mostly prevalent in pre-modern or preindustrial societies. It features a confrontational, public relation of power based on violence, which is deemed to belong to the so-called macro-physical level of power (Foucault 2006b: 26-27). Macro-physical means that relations of power are visible in the texture of society, they do not work secretly or disguised under the surface of the public. Quite on the contrary, they show off their violent sanctions against transgression of laws. Their paradigmatic punishment is the spectacle of public execution. Relations of sovereign power throughout society can be manifold, but they usually converge on a single point, a central sovereign, like a king or a feudal lord. They establish an asymmetrical relationship between a master and a subject. On the top there is security and maybe occasional gifts, at the bottom violence and punishment for the subject (Foucault 2006b: 42-44). The sovereign always represents a central power and below him are the subjects as an anonymous mass. This is 
crucial, because the sovereign remains an individual, whereas the subjects as individuals are of no particular interest to him, as long as they pay their debts to the sovereign.

On the other side of the spectrum stand the micro-physical disciplinary forms of power, which rose around the beginning of the 19th century in Europe. This type of power relations is itself almost undisclosed: 'It is an anonymous, nameless and faceless power that is distributed between different persons' (Foucault 2006b: 21). It is an almost mute force, not revealing its set of rules to its subjects, and establishes its hold beneath the surface of the public sphere (Foucault 2006b: 21-27). Contrary to sovereign power, it has a through and through interest in its subjects as individuals to a degree where it may justifiably be said to be obsessed with individuals. Disciplinary power represents a political actor, constantly observing, touching and infiltrating the bodies of its subjects, in order to accurately assess their modes of behaviour, habits and expression (Foucault 2006b: 40). In other words, it seeks for total appropriation of the body of the subjects, expressed by Foucault as the '...panoptic character of disciplinary power...' (Foucault 2006b: 52). Disciplinary societies do not only focus their control mechanisms on actual action, but also extend their enquiries to the potential act in the future. The future becomes the object of control: the discipline to come, the seed that should grow in every individual (Foucault 2001: 56-57). With its precise observation, disciplinary power tends to accumulate a huge corpus of data. The idea behind Foucault's conception is that this type of power is outstandingly productive in the sphere of knowledge and cannot be deemed only to be coercive. On the other hand, this does not mean that disciplinary societies are less oppressive than societies with sovereign relations of power, but as depicted above, their mechanisms of power enactment are more subtle.

Following these theoretical premises, the next section will be the first step to the analysis, by introducing the history of psychiatry and its ancestry of practice regarding the mentally ill in Japan.

\section{Archaeology of Japanese psychiatry}

Ancient Japanese medicine inherited almost completely the paradigm of classical Chinese medicine. The transmission of medical knowledge to Japan began in the 5th century, when the first doctors from Korea were invited by the emperor of Yamato 大和. From this point on, especially from the 6th century, Chinese medicine wielded the highest influence on Japan until the rapid import of Western scientific medicine in the 19th century, which led to the almost total abolishment of classical Chinese medical practice at that time (Hiruta 2002: 131-132). Not strictly discriminating between somatic and psychological phenomena, classical Chinese medicine was not in need of specialised psychiatric treatment. Since its common physiological com- 
prehension was based on the notion of $k i$ 気, which encompasses all the activities of a flux of energy enveloping both body and mind, the holistic pathological conception for psychological, psychosomatic as well as somatic symptoms was described as ki-chigai 気違い, considered to be a stagnating or dysfunctional flow of $k i$. Japanese pathological terminology, however, knew at least two fundamental concepts with which to frame classification of diseases commonly ascribed to the sphere of mental defects; these were called ten 廎 and kyo 狂. Considering the phenomenal descriptions of the terms in classic medical texts from the perspective of modern psychiatry, ten may represent the group of epilepsies and $k y \bar{o}$ that of psychoses. That these terms to some extent formed a standardised taxonomic system is well documented in the ancient Confucian legislative texts of ritsuryō 律令 (see Hayashi 2003 b). However, Kure stated that these terms were not exactly separated entities and were usually united in the notion of tenkyo 廎狂, a general expression for insanity. Kure remarks that it was widely used until its replacement by the modern psychiatric term of seishinbyō 精神病 for mental illness up to the 20th century (Kure 1903: 2). Another early document for descriptions of mental phenomena can be found in the Genji Monogatari 源氏物語, one of the most influential literary texts in the history of Japanese literature dating to the early 11 th century and according to psychopathologist Hayashi Yoshirō even a historical psychiatric resource (Hayashi 2003a: 197-200). It features passages dealing with the then widespread idea of the mentally ill as being possessed (monotsuki 物憑き) by monsters (bakemono 化け物), demons (mononoke 物の怪) and especially foxes (kitsune 狐). These creatures were supposed to enter the bodies of human beings in order to haunt their souls or to deliver divine messages. Foxes in particular were seen as summoned by gods and demons. For treatment, or more precisely for mediation, a priest from a nearby temple, or sometimes from a temple specialising in exorcism was habitually consulted, but rarely a doctor (Kure 1903: 12-13). This conception of patients being possessed sheds light on the approach to insanity at the time. Insane persons represented a chance to communicate with divine beings. Sometimes they were seen as mediums revealing acts of gods. The crucial point is that people listened to these persons and took their discourse seriously (see Foucault 2006a). In pre-modern times, until the late Tokugawa period, the majority of mentally ill were either treated in shrines and temples or often not treated at all. Unquestionably the most famous place for treatment of mental patients was the temple of Iwakura 岩倉 called Daiunji 大雲寺, of which it is said that mental illnesses were cured by its holy springs from as early as the 9th century (Kure 1903: 12). Another feature of the treatment concerning the mentally ill in pre-modern times, which is of tremendous importance for the following discourse analysis, is that these persons were almost solely accommodated in private houses with their families. In cases of acute fury or danger for other people, the patient was usually confined in a cell (zashikirō 座敷牢) attached to the house. These cells were also built to confine criminals or violent 
relatives (e.g. alcoholics) and by no means limited to the mentally ill. By common law, the family was accountable for all damage and harm caused by their family members (Totsuka 1990:193). The structure of these relations of power can be characterised as purely administrative and therefore belonging to the realm of sovereign power. A sovereign, be it the prefect of the village or the feudal lord, was not interested in individual issues of the subjects, as long as public peace was granted. Law did not discriminate between the actions of a criminal or a lunatic. It showed no interest whether an individual was considered dangerous or not, provided that the smallest administrative entity, e.g. the family, which shared responsibility for the acts of its individual members, settled the dispute. But the whole system should change fundamentally with the emergence of psychiatry in Japan.

\section{German and Austrian influence}

In 1869, just one year after the coming to power of the new Meiji government, a German medical school was introduced as offering the official academic medicine (Totsuka 1990: 193). This decision was a purely pragmatic one, because first of all, German-language medicine was already known in Japan, since the initial medical textbooks brought to Japan via the Netherlands at the end of the 18th century were German, and secondly, German and Austrian medicine was considered to be the product of the foremost advanced medical schools of the time (Ernst and Mueller 2010: 147). It should be kept in mind that Germany and Austria remained the cutting edge centres in medical sciences from the 19th up to the 20th centuries. Inasmuch as Japan adopted German-language medicine, a recapitulation of the dawn of Japanese psychiatry must begin by outlining the characteristics of these medical schools.

In his opus magnum Seishinbyōgaku-shūyō 精神病学集要 (Compendium of Psychiatry) (Kure 2002; 2003a; 2003b), Kure Shūzō stated that the two outstanding psychiatrists who affected his work the most were Richard von Krafft-Ebing (18401902) from Vienna and Emil Kraepelin (1856-1926) from Munich (Kure 2002: 4). The three giants of the first three generations of psychiatrists in Japan, Sakaki Hajime 椒俶, Kure Shūzō and Miyake Kōichi 三宅鉱一, all studied abroad, most notably in Austria and Germany. They all came under the direct influence of KrafftEbing and Kraepelin, some even being personal disciples of them (Omata 2002: 162-165).

Krafft-Ebing revolutionised psychiatry mainly by uniting two almost separately operating strands of psychiatry in the 19th century. On the one hand, he practised asylum psychiatry, dealing with the practical concerns of the daily routine in psychiatric institutions as the head of the famous Illenau lunatic asylum, but on the other hand he intensively studied brain-anatomic theoretical psychiatry under Wilhelm Griesinger (1817-1868), carried out in the academic ivory towers of university labs. 
Griesinger held that all psychopathological symptoms are rooted in diseases of the brain (Griesinger 1892: 1). Krafft-Ebing also declared mental diseases to be a subcategory of brain diseases and propagated the need to study mental illness in terms of its heritability and biological basis, but this did not stop him from reasoning about psychological factors in their course or treatment (Krafft-Ebing 1897: V-VII). He suggested the following reforms to psychiatry: psychiatric practice should be grounded in the foundations of experimental neurological knowledge generated in laboratories. This knowledge should then be transferred and tested in a clinical environment. In other words he propagated the institutionalisation of clinical psychiatry, because he thought that theoretical explanatory brain anatomy alone was not sufficient for an adequate account of mental illness and needed to be supplemented by descriptive psychopathology (Lesky 1965: 381-383). This critique of brain anatomy as the sole scientific method to explain the whole phenomenon of mental diseases was simultaneously deployed by another influential reformer of psychiatry. Emil Kraepelin in particular offered the criticism that the theoretical '... completeness [of brain anatomy] was multiply achieved on the grounds of experimentally unproven hypotheses' (Lesky 1965:377). Kraepelin, creator of the influential concept of 'dementia praecox' and a modern system of classification for mental diseases partially still in use today, even though he was convinced of the biological causes of mental defects (Kraepelin 1887: 2), was still sceptical of the capacity of brain neurology to fully explain all mechanisms involved in their genesis, progress and treatment. This was not because he thought neurology in principle would not be able to account for every physiological, psychological and psychopathological process, but simply because it had not yet reached its full scientific potential to detect irrevocable truths (Kraepelin 1887: 3). Hence he dedicated his work to a thorough, systematic description of mental illnesses. His revolutionary method consisted of detailed clinical observation of the progression of diseases instead of a statistical arrangement of isolated symptoms into patterns of diseases (Blasius 1994: 124-125). The crucial point in these psychiatric conceptions by Krafft-Ebing and Kraepelin is that they saw in psychiatry not only a theory of origin and treatment of diseases, but they also gave psychiatry the pragmatic role of an actor. Both regarded the duty of scientific psychiatry to be an active intervening agent in society. If psychiatry should reach its outright potential, it had to assume full socio-medical responsibility. Thus psychiatry imposed an obligation on the nation, or more precisely, the state had to accept its psychiatric obligation (Krafft-Ebing 1897: 21-23; Kraepelin 1900). Would this programmatic seed of psychiatry also grow in Japan? And what was it ultimately that would constitute the appeal of psychiatry to the state?

In general, political praxis in Japan at the onset of the 20th century was increasingly authoritarian and rigorously tried to confine threats to national identity, security, health or the kokutai 国体. (This term, roughly translatable as 'national polity', encompassed all kinds of meanings ranging from national essence or iden- 
tity, national or political body to Japanese sovereignty as the constitutional basis of the Emperor's power.) Many different kinds of diseases entered the discourse as serious threats to the nation, one being mental illness. While in Europe some of the epidemiological effects of industrialisation resulted in the institutionalisation of social medicine, in Japan this process had already been triggered earlier through epidemics brought to Japan from the West, which brought about extensive medical reform in 1868 and the opening of the first ministerial department of medicine in 1872. Modern Western medicine was gaining importance in order to counter Western diseases like cholera. In 1877 the second cholera epidemic swept through the country causing the government to erect quarantine hospitals. The population, not familiar with Western medical practice or institutions, was at least sceptical and resisted these new hygienic acts of the state. This resistance also applied to psychiatry. Often relatives would not leave their mental patients in psychiatric institutions, retaining the traditional custom of family care, simply because psychiatric hospitals were new, strange and had no particular support among the populace (Burns 2000: 18-27).

\section{Sakaki Hajime}

After the official introduction of German-language medicine to Meiji Japan, Sakaki Hajime was appointed in 1886 to the first academic professorship for psychiatry in the newly founded department of psychiatry of Tōkyō Teikoku Daigaku 東京帝国 大学, the Imperial University of Tōkyō. In 1883 he had gone to Germany to study Krafft-Ebing's psychiatry. By the following year he had already published a neurological paper in a major psychiatric journal (Sakaki 1884). This voluminous case study conducted at the mental hospital of the Charité in Berlin also featured an extensively detailed anamnesis of a patient (Sakaki 1884: 584-594). Upon his return to Japan he immediately began teaching biological psychiatry, blaming among other factors masturbation, homosexuality and other 'deviant behaviour' for sparking mental illnesses; however, in biological psychiatry the ultimate cause for psychopathological symptoms was always to be found in the physical constitution, especially of the nervous system. With the notion of psychological disposition and of the possibility of its hereditary transmission, the rise of eugenic concepts for social intervention seemed almost inevitable. The depiction of mental illness as hereditary degeneration clearly transformed mental diseases into an issue of social policy (Burns 2000: 36-37). A pamphlet issued by Sakaki in 1892 unmistakably entitled Tenkyō-in setsuritsu no hitsuyōo ron-su 癲狂院設立ノ必要を論ス (Discussion of the Urgency of Establishing Lunatic Asylums) (Sakaki 1892) strongly propagates the importance of a widespread institutionalisation of psychiatry on three grounds, firstly, the benefit of professional psychiatric care for mental patients; secondly, the 
benefit of security, because not only is psychiatry able to protect mental patients from themselves, but also, most importantly in order to legitimise psychiatry on a national level, it has to provide a functional protection of the general population from the mentally ill; and finally, the important role of psychiatry as the only scientifically proven, accurate means to detect the mentally ill among the healthy. Of course Sakaki added that since psychiatry had begun operating in the social space it had detected more and more mental diseases calling for an immediate extension of the number of psychiatric institutions throughout the country (Sakaki 1892: 1-4). It was precisely due to the menace of a gradual degeneration in the national body 'discovered' by psychiatry itself, that psychiatry demanded its own expansion as a social agent. Psychiatric hygiene would use this imagined process of gradual degeneration to evoke an apocalyptic vision of a whole nation corrupted by insanity (Burns 2000: 36-37). This may sound all too peculiar or even paranoid, but one has to keep in mind that at the same time, a military-economic race was taking place. The argument brought forward by psychiatric discourse, subtly nourishing the fears of the Meiji government, could be summed up as follows: in the race urging Japan to modernise rapidly in order to catch up with the ruling West so as to prevent colonisation, a large-scale degeneration in manpower would pose a substantial threat to the productivity of the nation. The pressing issue of national health was most evidently manifest in the teachings of the figurehead of Japanese psychiatry, Kure Shūzō, successor to Sakaki as professor of psychiatry at Tōkyō University.

\section{Kure Shūzō}

Kure, already trained in European psychiatric research methods by Sakaki, left Japan in 1897, heading to Austria. From 1899 he studied in Germany until his return to Japan in 1901 (Hashimoto 2010b: 161). He conducted research in the internationally celebrated laboratory of the Institute of Neurology of the University of Vienna under the distinguished neurological psychiatrist Heinrich Obersteiner (1847-1922), and obtained state-of-the-art neurological skills. A publication in the Jahrbücher für Psychiatrie und Neurologie (Psychiatry and Neurology Yearbook) (Kure 1899) earned him the approval of the international scientific community, although earlier, in 1894, Kure had already established himself as a leading scientific authority in psychiatry in Japan after releasing the first volume of his Seishinbyōgaku-shūyō 精 神病学集要 (Kure 2002). This work unquestionably marks one of the most important cornerstones for psychiatric discourse in Japan (see Takahashi 1997: 35). In its preface Kure emphasised the importance of psychiatric hygiene concerning matters of national health. As this is a crucial point, the passage is quoted at length.

Hygiene is a pressing issue for the nation. The weakness or strength, the poorness or richness of a country is in a large part determined by its people's health. It is of utmost import- 
ance to the nation especially to avoid degenerative and hereditary diseases. It is estimated that in countries with a high rate of mental diseases one out of 500 is sick. If this is true for our nation, it follows that out of 40,000,000 people, 80,000 are mentally ill. Mental illness destroys the nervous system, which is the host of the mystic wisdom of mankind. It is degenerative and is frequently inherited by our descendants. If we do not address the issue of stopping [this process] right now, the situation will keep getting worse every year. This will have a tremendous impact on the productivity and performance of our whole nation (Kure 2002: VIII). ${ }^{1}$

In another publication on suicide and mental illness in the Jahrbücher für Psychiatrie und Neurologie, written by Kure during his stay in Vienna, he holds that the threat of reduced productivity posed by mental diseases is by no means a minor matter in psychiatric discourse. The first lines of the article read:

That suicide influences the productivity of a state and that it represents an important factor in the fluctuation of the population is evident. Having said this, it has been treated in statistics on the fluctuation of the population and registration of deaths respectively. Some people see it as a natural phenomenon and hold that in this case too human will is bound to the law of nature; although this cannot imply that it is by no means at all possible to avert it or to prevent it.

Suicide statistics from Europe as well as from our country prove that the majority of suicidal persons are driven to the act by mental diseases. It follows that scientific research on suicide is very important for us doctors (Kure 1898: 271).

At the end of the paper he unsurprisingly connects the problem of suicide to the heredity of mental illnesses. Kure states that although the relative number of suicides without hereditary predisposition of 22.97 percent is considerably higher than of those with hereditary deficiencies (11.39 percent), it is demographically insignificant if compared with absolute numbers, because he claims that in 887 cases mental illnesses were inherited and in only 101 cases they were not (Kure 1898: 296-297). The text stresses the seriousness of suicide and at the same time informs the discourse of hereditary mental illnesses with the notion of a hazard to the nation. Immediately upon his return from Germany, Kure started an intensive campaign for the increase of psychiatric institutions among lobbyists. Prior to the emergence of psychiatry in Japan the mentally ill were confined for a period necessary to restore public peace, but they were not necessarily diagnosed or treated by a doctor. A threat was posed by a dangerous act, not by a dangerous person and certainly not by a degenerative genealogy. Mental diseases were not considered to be hazardous diseases. In focusing on mental illness as a threat, psychiatry subtly shifted the perspective of the discourse surrounding the mentally ill to the whole being and all the facets of its life, or to put it in Foucauldian terms, to the total ontological mode

1 All translations from German and Japanese into English are the work of the author. 
of the subjects, in order to assess their potential dangerousness to society (Foucault 2003: 16). The theme of mental 'diseases' is bound to the appearance of modern psychiatry itself. To put it in the words of science and technology studies (STS): the phenomenon of mental diseases in the strict sense of disease is co-produced by scientific psychiatry. Co-production in this context means a strictly symmetric process of power and knowledge formation, so that every form of power produces new forms of knowledge, while new forms of knowledge produce different forms of power relations. These processes have to be seen as simultaneous and interwoven. This leads to the fundamental thesis of the emerging field of STS that society and science are co-produced (for a detailed account on the notion of co-production, see Jasanoff 2004).

Besides its humanistic mission to improve the situation of the mentally ill, psychiatry of the 19th and 20th centuries pursued a course as a social medical agent. Every social medical effort is defined by one central question, that of epidemiology. How do mental diseases spread? They may not be contagious, but if they seem to be hereditary, which target group will attract the interest of psychiatry? According to Kure, analysing and stopping the hereditary process of mental diseases throughout the national body was of the utmost importance. The logical conclusion would be to look for signs of mental illnesses in the early stages of ontogenesis in order to stop the dissemination of diseases, meaning that children are to become the designated target group of psychiatric expertise. In the second volume of the Seishinbyogaku$s h \bar{u} y \bar{o}$ 精神病学集要(Kure 2003a), dedicated to the cause of mental illness, he cites an alarming graph which demonstrates the large proportion of adolescent patients among the inmates of the Heidelberg Psychiatric Hospital (Kure 2003a: 338). Kure continues with a chapter on mental illnesses of adolescence, a critical phase in the genesis of an individual involving huge transformations of body and soul. He cites another empirical study suggesting that 42 percent of the mentally ill already develop symptoms between the age of 16 and 20 (Kure 2003a: 339). Psychiatrists would now have to acquire the skills to decipher the process of development of an individual. Body and mind in a subject transform into a series of signs, and the task of the paediatric psychiatrist consists of detecting those signs that indicate a significant pathogen risk. The notion of 'degenerative signs' would be of great help to fulfil this duty. Kure does not hesitate to list a few of these ominous signs: the tendency to hallucinate, slight hallucinations, tendency to exuberant fantasy, mood swings, abnormal pessimism or optimism, credulousness, bad habits, libidinousness, deviant sexual drive or obsession. The list represents an overly fuzzy and not too precise collection of criteria. Presumably every single teenager now and then would show one or more of these 'degenerative signs'. All these 'stigmata hereditaria', Kure states, may be found also among the healthy, but with considerably lower distribution (Kure 2002: 308). It follows that a professional psychiatrist would be 
required to read and measure the severity of the signs. Within a decade Kure had written a featured textbook on paediatric psychiatry (Takahashi 1997:34).

\section{Miyake Kōichi}

The programme of early detection of psychopathological signs was particularly pursued by Kure's successor at the Imperial University of Tōkyō, Miyake Kōichi, the third grandmaster of Japanese psychiatry. His Seishinbyōgaku-teiyo 精神病学提 要 (Abstract of Psychiatry), published in 1932, contained a list of degenerative signs covering three full pages (Miyake 1938: 85-87). Miyake would further succeed in introducing a new notion and a method for detecting mental disorders in children tightly connected to the concept of mental weakness. In 1905, upon Kure's recommendation, Miyake studied abroad for two years in Germany and Austria, mostly under Kraepelin's supervision in Munich, where he encountered the concept of 'arrested development'. Like the textbook of his mentor Kraepelin, his own psychiatric textbook section on psychopathology concluded with descriptions of different forms of arrested development (see Kraepelin 1887: 507-532; Miyake 1938: 395421). Depending on its stage, arrested development was considered to cause different kinds of mental weaknesses, with idiocy being a severe form. According to Kraepelin, the specific problem of the pathology of the child is composed as follows:

The organism is affected by the pathogenic at a time when the psychic personality is still incomplete and it generates a product that in its essential structure will persist unaltered and incurable for the rest of its life (Kraepelin 1887:507).

It is now evident why Miyake dedicated his work to the search for new methods to detect mental deficiencies, for it was a race against the clock of juvenile ontogenesis to protect the nation from its dispersal. In his search for a new key to discriminate between 'normal' and 'abnormal' individuals, Miyake discovered the notion of intelligence (Takahashi 1997: 37). This effort resulted in the publication of the first intelligence test in a Japanese medical journal (Miyake and Ikeda 1908). An intelligence test allows psychiatrists to assess easily the individual's logical capacity through a standardised scientific form in order to define it according to the code normal-abnormal. But even Miyake, the advocate of intelligence tests, would not claim that they could give a sufficient profile of a whole individual being. So the intelligence test was considered to be only the first step in a total evaluation of the 'normality' of a subject including a full survey of physical symptoms, sensibility, emotions, mode of life, behaviour and the like (Takahashi 1997: 38). This evaluation would ultimately determine the lebensraum of abnormal individuals, because according to Miyake, unsurprisingly, all 'idiots' should be segregated from society and 
confined in special asylums (Miyake 1938: 410). In 1937, the psychiatrist Sugita Naoki 杉田直樹, who had also studied under Kraepelin, finally established an asylum solely for 'abnormal' and 'mentally weak' adolescents. He would write numerous psychiatric expert treatises on children across all prefectures to further push the practice of paediatric psychiatry. For Takahashi Satoru 高橋智, who published a paper on the history of the concept of mental weakness in Japan, Sugita remains one of the single most dedicated scholars to transform the issue of mental weakness into a social matter (Takahashi 1997:39).

All this scientific psychiatric discourse, which threatened to invade the private space of the population, was partly challenged by a strong public vein of critical journalism. For example, Yomiuri Shimbun 読売新聞 published a series of articles dealing with the rise of mental illnesses among the population in sociological parameters, as opposed to biological psychiatry. Some journalists regarded mental illnesses to be a result of poor social circumstances originating in the reckless industrialisation promoted by the government (Burns 2000: 40-45). In 1901, Yomiuri Shimbun further published an article on cases of abuse and corruption in seven psychiatric institutions of Tōkyō (Suzuki 2003a: 220). This leads to the following questions: why was psychiatry even considered necessary when it did not seem to have been backed by society? How was the newly arrived discourse of psychiatry in a relatively short period of time able to achieve the position of an agent of the political regime in Japan?

\section{Law and psychiatry}

On July 14, 1853, the 'black ships' of Commodore Matthew Calbraith Perry (17941858) arrived in the bay of Uraga 浦賀 and the United States (US) forced Japan to end its policy of isolation, which had lasted more than two centuries, vis-à-vis the West. The US, followed by the European powers, imposed a trade agreement upon Japan containing numerous unequal conditions, the infamous fubyōdojoyaku 不平等 条約 or 'unequal treaties'. They granted Western visitors to Japan the status of extraterritoriality and low import tariffs for foreign goods. These treaties were to affect Japan's political and economic development far beyond the Meiji restoration. Whereas China tried to oppose its own unequal treaties with an unsuccessful war, Japan met the requirements of the Western powers. This meant the loss of its competence to regulate its own export duties, in other words a loss of economic sovereignty (Marutschke 1999: 34). The Tokugawa shogunate, unable to deal with the situation, was overthrown, leading to the Meiji restoration of 1868, probably the most profound transformational break in the history of Japan. After unsuccessful attempts to reform the law in terms of classical Chinese law, the Meiji government quickly recognised that the only way to revise the unequal treaties as soon as pos- 
sible was to erect a whole new legal architecture. In order to be on a par with the West, Japan saw its only chance in a rapid implementation of a modern Westernstyle legal system, besides raising a powerful army. At the same time, introduction of a new centralised juridical structure allowed some welcome social engineering within Japan's borders, such as the powerful tool of land tax, granting domestic political stability. The Meiji regime accomplished the installation of a modern legal system with unparalleled speed. Only 15 years after the restoration the government established a penal law and after another seven years the Meiji constitution, based on the Prussian constitution and valid until 1945 (Igeta 2006: 28). In 1894, this strategy turned out to be effective for the very first time when Japan successfully revised its unequal treaty with Great Britain. Other countries followed up until 1911, by which time Japan had fully restored its customs regime sovereignty. This absolutist top-down revolution not only exploited the domestic population, but also neighbouring regions: in 1876, Japan imposed its own version of an unequal treaty upon Korea, exactly reproducing the imperial gesture of the Western powers.

In order to understand the discursive bonding of law and psychiatry, we will have to focus on the penal law, because psychiatry will assume its very special forensic position within that system. Shortly after the enactment of the penal code of 1880 discussion started once more. Especially in the eyes of proponents of the logicaldeductive school of German legal theory many of the notions were adopted from the French code pénal and seemed to be too diffuse. These theorists argued further that the penal code should explicitly mirror the conservative national cause of the constitution. Between 1890 and 1899, different drafts were handed to parliament until the new penal code was passed in 1907 (Schenck 1997: 315-318). The new German school of penal law particularly influenced Japanese legal thought. It featured a whole new rationale in focussing on the dangerousness of a subject as a basis for assessing the sentence, because it considered the penal code as a means of defending society against its 'enemies' (Fukuda 1989: 57-58). This represents a completely different set of issues compared to the questions that classical Chinese law was dealing with. Chinese or traditional Japanese law was based on the fundamental human capacity to discriminate between good and evil. Within this conception punishment was actually seen as retaliation. Modern Japanese law subtly transformed the object of the penal code from an evil individual act to a threat to society. Thus, the penal code more and more gained the character of a preventive intervention in the social space. The new concept of the 'enemy from within' was coined, giving birth to a radically novel discourse of enemies and dangers to society not at all limited to the legal theory of the 19th century (Serizawa 2001: 23-33). Discourses informed by this logic did not deploy the classic legal dichotomy of transgression and sanction, but showed more interest in the hazardousness of a subject. This formation could be accurately grasped as the emergence of the disciplinary in the realm of the juridical. The disciplinary is not restricted to juridical power; it gives 
rise to a new form of power relations. It constitutes a delocalised mechanism of power fitting any given discourse or, in other words, is an apparatus (Tadros 1998: 95). The entanglement of law and psychiatry exactly takes place at this intersection of the disciplinary apparatus.

Until the instalment of the modern Japanese juridical system, there was no specific legal act to codify the handling of mentally ill persons (Totsuka 1990: 193194). When in 1900 the Mental Patients Custody Act was passed, it just regulated the traditional practice of family care by subjecting it to police administration. It stipulated a registered person responsible for the custody (kango 監護) of every mental patient monitored by local government officials (Suzuki 2003a: 198-199). The reasons for passing this law were twofold: first, as mentioned above, Japan had to introduce a modern legal system in order to catch up with Western powers, which also included a legal framework for the treatment of the mentally ill. Although it would have been impossible to build an all-encompassing system of asylums to accommodate mental patients as in Europe and the US in this relatively short period of time, state-controlled family care seemed to be a suitable system for the dilemma (Nakatani 2003: 194). Secondly, a new state-controlled but traditional model of care additionally provided a solution for domestic issues. In this perspective it was the reaction to protests across the country regarding cases of illegitimate private confinement. In 1885, the infamous Sōma incident (Sōma-jiken 相馬事件) was exposed to the public. The former daimyō 大名 Sōma Tomotane 相馬誠胤 was confined for years under the questionable premises of mental illness, even though there was no initial diagnosis by an official let alone a medical professional. A 'static warfare' of different surveys from different administrative, medical and psychiatric authorities took place between Sōma's family and his loyal servant, who untiringly tried to free his master from confinement until Sōma's death in 1892 (Kargl 1987: 19-21). This incident was an immediate consequence of Sōma's ambiguous legal position. It caused public resentment that even reached the European media. Bearing in mind that the Soma incident was not an isolated case, instances of illegitimate confinement on the grounds of alleged mental illness could be compared to the misuse of the lettre de cachet in 18th-century France, a common practice by which citizens could write a letter to the king asking for confinement of a specific person. Both customs frequently practiced the confinement of undesirable people under the pretence of mental illness (see Suzuki 2003a: 198-199; Castel 1983: 26-27).

An expert view of 1917 stated that out of 65,000 mentally ill, roughly 4,500 were confined in private cells and 5,000 accommodated in private and public asylums, leaving the other 55,000 unattended (Nakatani 2003: 195). Kure Shūzō vigorously criticised these fatal conditions. In 1918 he published the results of a sociopsychiatric field study about the private detention of mental patients across the nation. Seishinbyōsha shitakukanchi no jikkyō oyobi sono tōkeiteki kansatsu 精神病 者私宅監置ノ実況及ビ其統計的観察 (The Situation of Private Custody of the 
Insane and Its Statistical Survey) (Kure and Kashida 2009) contained 115 cases of private imprisonment with a statistical assessment of the reasons for confinement. Domestic violence unsurprisingly was the most common reason, strangely followed by 'aimless wandering' with 16.5 percent (Kure and Kashida 2009: 109). For the psychiatrist Kure this was an unbearable situation, and not only because of the inhuman conditions of numerous cases of private detention in cells, which he criticised; in his eyes mental patients were not simply to be confined, for they had to be treated, studied and analysed by trained psychiatrists. With the aid of his scientifically backed survey, Kure first of all raised a lobby of high-rank government officials and ministers, which actually resulted in the enactment of the Mental Hospital Act in 1919. It unmistakably regulated the confinement of violent, dangerous and severe cases of mentally ill in a psychiatric hospital. The public discourse surrounding mental illness at that time was already driven by the myths of hereditary degeneration and by obscurity and was increasingly expressed in terms of danger. Gradually it was depicted as a dangerous disease as well as a threat to public peace and health (Totsuka 1990: 194). Clearly the concept of the dangerousness of a subject was slowly rising to the surface of the discourse.

In a public address to the House of Commons in 1918, Saitō Kiichi 斉藤紀一, an army officer and at the same time founder of the famous Aoyama Nōbyōin 青山脳 病院 (Aoyama Brain Hospital), strongly pushed the issue of dangerous, insane criminals wandering about in the public space to the fore. Strikingly, he did not depict the mentally ill as wild animals, but painted their dangerousness in a much more refined tone. According to Saitō, the real threat was not posed by apparently raving maniacs, but by silently operating lunatics such as monomaniacs, who appeared as normal people. They were dangerous for their 'invisibility'. He even accused the government of negligence for allowing those potential murderers, rapists and thugs to walk around freely. At the end of his speech he emphatically called for a broad extension of psychiatric institutions in Japan (Suzuki 2003a: 202). At this point we are able to observe very clearly the discursive divide separating premodern practice and modern legal psychiatry. In pre-modern times the mentally ill person was only dangerous in the case of a hazardous act. Mental illness was not an issue in itself, only in terms of police administration for the safety of the community. Then, with the advent of psychiatry and modern legal thought the potential dangerousness of a mentally ill subject emerged and now the circle closed with the seeming invisibility of the real danger of mental diseases. The solution to the problems raised by this invisibility, calling for an agent who was able to detect these threats among society is evident: the master of the scientific detection of potential threats to the nation is of course the psychiatrist. The very real consequences of this discursive shift were an actual reversal of the proportions of privately accommodated mental patients and hospitalised ones between the 1920s and the 1930s (Suzuki 2003a: 
206). By 1940, the number of hospitalised patients was already double the number of patients in private care (Suzuki 2003a: 206).

In order to detect the mentally ill among 'normal' criminals or the general populace the formation of a new speciality in psychiatry was required: forensic psychiatry. It was born from the intersection of medical and legal discourse. It was an absolute necessity for the legitimisation of psychiatric discourse as well as for the solution of a juridical dilemma. If the law, lacking methods to detect mental diseases, nonetheless had to deal with the threat legally, an immediate problem arose: the law might segregate criminal threats to society by confining the criminals in prisons, but what about the potentially dangerous mentally ill, who did not break the law? Apparently, the mentally ill were wandering about a legal no man's land (Castel 1983: 51). The Japanese penal code inherited the famous European legal proposition that mentally unfit subjects or subjects not in full possession of their mental capacities cannot be prosecuted under the law (Nakatani 2003: 197). Forensic psychiatry filled this legal loophole by providing scientifically legitimised methods to make them visible and at the same time constructed the legal basis for separating them from society by confinement to a mental institution. The forensic psychiatric examination, ultimately deciding if an individual was mentally ill or not, became a central vehicle for psychiatric practice. Krafft-Ebing claimed that the forensic psychiatric examination, being one of the most important psychiatric skills, should not be absent from any forensic medical curriculum (Krafft-Ebing 1892: 23). Sakaki also pointed out that the forensic examination is a tool for jurisdiction of the utmost importance (Sakaki 1892:3), while Kure dedicated more than one hundred pages of his Compendium to psychiatric examinations (Kure 2003b: 789-866). Naturally a full psychiatric assessment of an individual cannot be conducted within the barriers of a courtroom. An adequate evaluation of a complex psychic entity like a human being may only be sufficiently provided through total observation: 'Forensic psychopathology today insists on being a synthesis, taking into account the whole individual in all their physical and mental relations, as well as their history and a mode of assessment that comprehends their present existence...' (Krafft-Ebing 1892: 28). This could be read as meaning that an individual in question should be delivered to a psychiatric institution for a close examination. In the notion of the forensic psychiatric examination one can observe how the whole juridical justification strategy of psychiatric discourse unfolds.

\section{Conclusion}

I will now conclude the present survey by analysing the two central legal acts that codified the treatment of the mentally ill in Japan through the theoretical framework 
of sovereign and disciplinary relations of power as stated in the beginning of this paper.

The Mental Patients Custody Act passed in 1900 can obviously be defined as emerging from sovereign relations of power. It operated as a police-administrative order bound first of all to end the confusion of legal diffuseness. The legal text clearly stated: 'The custody of a mentally ill person is the duty of the custodian... A person other than the custodian is not allowed to confine the mentally ill... If a mentally ill person is to be confined, permission of the administration department has to be requested' (cit. in Kargl 1987: 317). These three sentences should have dissolved the confusion over the malpractice of private confinement. The sovereign was represented by a custodial authority, at the first level a relative, at the second level an official, commissioned to punish or confine the mentally ill subject. In this process there seemed to be no need of a medical professional. The traditional model of family care only arranged temporary confinement in private cells integrated into the house in the case of danger to the community. This form of care for the mentally ill persisted withstanding reforms and law enactments, especially in rural regions away from the central government's power (Suzuki 2003a: 223-224). This act of law marks the point of inflexion from pre-modern to modern times, but its identity is fractured. An amalgamated law combining different orders of rationality, the Mental Patients Custody Act resided in the discursive divide between the dusk of sovereign power and the dawn of a disciplinary society. Essentially it codified a pre-modern practice, which should be enacted through a modern juridical directive, operating in the order of sovereign power. Although it already disposed of modern legal techniques, it nevertheless expressed sovereign relations of power.

The Mental Hospital Act on the other side, deployed under the tremendous influence of psychiatry, is clearly an enactment of disciplinary power. In a psychiatric hospital, power is not embodied by one sovereign person. It is embodied in an attendant, a diagnosing psychiatrist or an observing anonymous doctor. Outside of the institution disciplinary power mediated by law may be enacted by the family, which requests the confinement through a government official, who is commanded by the governor to execute it. In any case, a medical assessment is necessary: 'A governor may commit a mentally ill [person]...to a psychiatric hospital...The diagnosis of a doctor according to the edict is required for the hospitalisation of the mentally ill [patient]' (Kargl 1987: 321). Furthermore, psychiatric power remains silent towards its subject. Kure used the assessment methods of Kraepelin, who held that only the precise observation of the patient's course of disease was crucial for a successful diagnosis. Psychiatrists using his methods usually engaged only in rudimentary conversation with the patient, because they considered it to be more important to observe them than to speak to them (Burns 2000: 40). This may also explain the common practice of Japanese psychiatrists not to communicate at length with a patient and to write their notes in a few German words. German long remained the 
scientific language of medicine in Japan. Some medical terms deriving from German everyday language were even used to convey esoteric-scientific notions by Japanese doctors (Doi 1973: 14). As mentioned above, psychiatric methods relied on a total capture of the complete ontological modes of their subjects in order to provide adequate diagnosis and therapy. The mentally ill therefore had to be institutionalised in a mental hospital for constant observation and needed to be kept hospitalised for as long as possible to allow their aetiopathology to be fully grasped. If we examine the periods of residence of patients in a psychiatric hospital, it is striking to compare the length of stay between patients who have been hospitalised on private and those who were detained on public initiative. Whereas the majority of private patients usually stayed between a few days to a maximum of one year, the majority of the public hospitalised usually had to stay from one year at least up to four years ( $\mathrm{Su}-$ zuki 2003a: 222). From an overall perspective hospitalisation rates at the beginning of the 20th century tended to be still very low in Japan. At the peak of hospitalisation between the 1930s and the 1940s it was estimated that just about 30 percent of the mentally ill throughout the country were accommodated in a psychiatric institution (Suzuki 2003a: 217); a surprisingly low rate considering the efforts of Japanese psychiatrists. This low confinement rate '...show[s] the persistence of informal domestic care without recourse to either hospital or home custody, long after the Mental Patients Custody Act and Mental Hospitals Act' (Suzuki 2003a: 217). It seems that the success of the project of psychiatric discourse was not at all inevitable, because we will now re-encounter a relevant aspect of disciplinary societies: 'If we talk about a "disciplinary society", then by no means should we grasp it within the meaning of a "disciplined society" (Foucault 2005: 20). Hence by aid of psychiatric discourse, Japanese society of the late 19th and early 20th centuries may also be defined as a disciplinary society, but maybe not as a disciplined society. 


\section{REFERENCES}

Blasius, Dirk. "Einfache Seelenstörung”: Geschichte der deutschen Psychiatrie 1800-1945. Frankfurt am Main: Fischer Taschenbuch Verlag, 1994

Botsman, Daniel. Punishment and Power in the Making of Modern Japan. Princeton and Oxford: Princeton University Press, 2005

Burns, Susan. "Constructing the National Body: Public Health and the Nation in NineteenthCentury Japan." In Nation Work: Asian Elites and National Identities, edited by Timothy Brooks and Andre Schmid. Ann Arbor: The University of Michigan Press, 2000, pp. 17-49

Castel, Robert. Die psychiatrische Ordnung: Das goldene Zeitalter des Irrenwesens. Frankfurt am Main: Suhrkamp, 1983

Derrida, Jacques. Writing and Difference. London and New York: Routledge, 1978

Derrida, Jacques. Of Grammatology. Baltimore and London: John Hopkins University Press, 1997

Doi, Takeo. The Anatomy of Dependence. Tokyo and New York: Kodansha International, 1973

Ernst, Waltraud, and Thomas Mueller, eds. Transnational Psychiatries: Social and Cultural Histories of Psychiatry in Comparative Perspective, c. 1800-2000. Newcastle upon Tyne: Cambridge Scholars Publishing, 2010

Foucault, Michel. The History of Sexuality. Vol. I: An Introduction. New York: Pantheon, 1978

Foucault, Michel. Discipline and Punish: The Birth of the Prison. New York: Vintage, 1995

Foucault, Michel. Power: Essential Works of Foucault 1954-1984, vol. 3. New York: New Press, 2001

Foucault, Michel. Archeology of Knowledge. London and New York: Routledge, 2002

Foucault, Michel. Abnormal: Lectures at the Collège de France 1974-1975. London and New York: Verso, 2003

Foucault, Michel. Dits et ecrits. Band 4: 1980-1988. Schriften. Frankfurt am Main: Suhrkamp, 2005 [An English translation of the discussion can be found in: Maurice Aymard, ed. French Studies in History, vol. 2. New Delhi: Orient Longman Limited, 1990, pp. 323-333]

Foucault, Michel. History of Madness. London and New York: Routledge, 2006a

Foucault, Michel. Psychiatric Power: Lectures at the Collège de France 1973-74. New York: Palgrave, 2006b

Fukuda, Taira. "Die Beziehung zwischen der deutschen und der japanischen Strafrechtswissenschaft. Eine historische Studie.” In Strafrecht und Kriminalpolitik in Japan und Deutschland, edited by Hans Joachim Hirsch and Thomas Weigend. Berlin: Duncker und Humblot, 1989, pp. 57-63

Griesinger, Wilhelm. Pathologie und Therapie der psychischen Krankheiten für Ärzte und Studierende. Berlin: Verlag von August Hirschwald, 1892

Hashimoto, Akira 橋本明. Chiryō no basho to seishiniryōshi 治療の場所と精神医療史 [The Place of Cure and the History of Psychiatric Care]. Tōkyō: Nihon Hyōronsha, 2010a

Hashimoto, Akira. "The Invention of a 'Japanese Gheel': Psychiatric Family Care from a Historical and Transnational Perspective." In Transnational Psychiatries: Social and Cultural Perspective, c. 1800-2000, edited by Waltraud Ernst and Thomas Mueller. Newcastle upon Tyne: Cambridge Scholars Publishing, 2010b, pp. 142-171

Hayashi, Yoshirō. “Mental Illness in the Tale of Genji.” In Gifu daigaku igakubu kiyō 岐阜大学医 学部紀要 [Bulletin of the Medical Separtment of Gifu University] (Acta Scholae Medicinalis Universitatis Gifu), 51, 2003a, pp. 197-200 
Hayashi, Yoshirō. "The History of Psychiatry in Japan: Notional Changes before the Modern Ages.” In Gifu daigaku igakubu kiyō 岐阜大学医学部紀要 [Bulletin of the Medical Department of Gifu University] (Acta Scholae Medicinalis Universitatis Gifu), 51, 2003b, pp. 245248

Hiruta, Genshirō. "Japanese Psychiatry in the Edo Period (1600-1868).” In History of Psychiatry, 13, 2002, pp. 131-151

Igeta, Ryōji. "Reform of Law in the Meiji Restoration." In Beiträge zur modernen japanischen Rechtsgeschichte, edited by Hans-Peter Marutschke. Berlin: Berliner Wissenschaftsverlag, 2006, pp. 28-52

Jasanoff, Sheila, ed. States of Knowledge: The Co-Production of Science and Social Order. London and New York: Routledge, 2004

Kanekawa, Hideo 金川英雄, and Hori Miyuki 堀みゆき. Seishinbyoin no shakaishi 精神病院の 社会史 [Social History of the Psychiatric Hospital]. Tōkyō: Seikyūsha, 2009

Kargl, Ingrid. Ausgestoßen - Eingeschlossen: Die Hospitalisierung psychisch Kranker in Japan. Wien: Institut für Japanologie der Universität Wien, 1987

Kraepelin, Emil. Psychiatrie: Ein kurzes Lehrbuch für Studirende und Aerzte. Leipzig: Verlag von Ambrosius Abel, 1887

Kraepelin, Emil. Die psychiatrischen Aufgaben des Staates. Jena: Verlag von Gustav Fischer, 1900

Krafft-Ebing, Richard von. Lehrbuch der gerichtlichen Psychopathologie: Mit Berücksichtigung der Gesetzgebung von Österreich, Deutschland und Frankreich. Stuttgart: Verlag von Ferdinand Enke, 1892

Krafft-Ebing, Richard von. Lehrbuch der Psychiatrie: Auf klinischer Grundlage für praktische Ärzte und Studierende. Stuttgart: Verlag von Ferdinand Enke, 1897

Kumasaka, Yoshino, and Yoshioka Shinji. "The Law of Private Imprisonment: Fifty Dark Years for the Mentally Ill in Japan." In American Journal of Psychiatry, 125/2, 1968, pp. 213-216

Kure, Shūzō. "Ueber Selbstmord und Selbstmordversuch bei Geisteskranken.” In Jahrbücher für Psychiatrie und Neurologie, 18, 1898, pp. 271-297

Kure, Shūzō. "Die normale und pathologische Structur der Zellen an der cerebralen Wurzel des Nervus trigeminus, die Kreuzungsfrage der letzteren und der motorischen Trigeminuswurzel." In Jahrbücher für Psychiatrie und Neurologie, 18, 1899, pp. 158-181

Kure, Shūzō. "Geschichte der Psychiatrie in Japan." In Jahrbücher für Psychiatrie und Neurologie, 23, 1903, pp. 1-17

Kure, Shūzō 呉秀三. Seishinbyōgaku-shūyō, Zenpen 精神病学集要. 前編 [Compendium of Psychiatry, vol. 1]. Tōkyō: Sōzō Shuppan, 2002 [1894]

Kure, Shūzō 呉秀三. Seishinbyōgaku-shūyō, Chūhen 精神病学集要. 中編 [Compendium of Psychiatry, vol. 2]. Tōkyō: Sōzō Shuppan, 2003a [1895]

Kure, Shūzō 呉秀三. Seishinbyōgaku-shūyō, Kōhen 精神病学集要. 後編 [Compendium of Psychiatry, vol. 3]. Tōkyō: Sōzō Shuppan, 2003b [1895]

Kure, Shūzō 呉秀三, and Kashida Gorō 樫田五郎. Seishinbyōsha shitakukanchi no jikkyō oyobi sono tōkeiteki kansatsu 精神病者私宅監置ノ実況及ビ其統計的観察 [The Situation of Private Custody of the Mentally Ill and Its Statistical Evaluation]. Tōkyō: Sōzō Shuppan, 2009 [1918]

Lesky, Erna. Die Wiener medizinische Schule im 19. Jahrhundert. Graz and Köln: Verlag Hermann Böhlaus Nachfolger, 1965

Marutschke, Hans-Peter. Einführung in das japanische Recht. München: C.H. Beck'sche Verlagsbuchhandlung, 1999 
Miyake, Kōichi三宅鉱一. Seishinbyōgaku-teiȳ̄ 精神病学提要 [Abstract of Psychiatry]. Kyōto; Tōkyō: Nankōdō, 1938

Miyake, Kōichi 三宅鉱一, and Ikeda Takanori 池田隆徳. “Chiryoku-sokutei-hō” 知力測定法 [Methods for Intelligence Measurement]. In Igaku-chūo-zasshi 医学中央雑誌 [Japanese Central Journal of Medicine] (Japana Centra Revuo Medicina), 66, 1908, pp. 242-258

Munslow, Alun. Deconstructing History. New York: Routledge, 2006

Nakatani, Yōji 中谷陽二. “Nihon no seishiniryōshi to shokuhō-seishinshōgaisha” 日本の精神医 療史之触法精神障害者 [History of Psychiatry and the Delinquent Mentally Ill in Japan]. In Seishin shinkeigaku zasshi 精神神経学雑誌 [Japanese Journal of Psychiatry and Neurology] (Psychiatria et Neurologia Japonica), 105/2, 2003, pp. 194-199

Omata, Waichirō 小俣和一郎. Kindai seishinigaku no seiritsu: “Kusarikaihō" kara nachizumu e 近代精神医学の設立.「鎖解放」からナチズムへ [The Emergence of Modern Psychiatry: From 'Liberation from the Chains' to Nazism.]. Kyōto: Jinbun Shoin, 2002

Porter, Roy, and David Wright, eds. The Confinement of the Insane: International Perspectives, 1800-1965. Cambridge: Cambridge University Press, 2003

Sakaki, Hajime. “Aus der Nervenklinik der Charité (Prof. Westphal): Ueber einen Fall von Tabes dorsalis mit Degeneration der peripherischen Nerven." In Archiv für Psychiatrie und Nervenkrankheiten, 15, 1884, pp. 584-594

Sakaki, Hajime 榊俶. Tenkyō-in setsuritsu no hitsuyō o ron-su: Kokka-igakudai-ichi-gō 癲狂院設 立ノ必要习論ス. 国家医学第一号 [Discussion of the Urgency of Establishing Lunatic Asylums: National Medicine Number 1]. Tōkyō: Tanaka Giichi, 1892

Schenck, Paul-Christian. Der deutsche Anteil an der Gestaltung des modernen japanischen Rechts- und Verfassungswesens: Deutsche Rechtsberater im Japan der Meiji-Zeit. Stuttgart: Franz Steiner Verlag, 1997

Serizawa, Kazuya 芹沢一也. Hō kara kaihō sareru kenryoku: Hanzai, kyōki, binkon, soshite taishō-demokurashii 法から解放される権力. 犯罪、狂気、貧困、そして大正デモクラシ — [The Power Released from Law: Crime, Insanity, Poverty and Taishō Democracy]. Tōkyō: Shinyōsha, 2001

Serizawa, Kazuya 芹沢一也. Kyōki to hanzai: Naze nihon wa sekai'ichi no seishinbyō kokka ni natta no ka 狂気と犯罪. なぜ日本は世界一の精神病国家になったのか [Insanity and Crime: Why Japan became Number One of the States of the Mentally Ill in the World]. Tōkyō: Kōdansha, 2005

Serizawa, Kazuya 芹沢一也. Horaahausu-shakai: Hō o okashita “shōnen” to “ijōsha” tachi ホラ 一ハウス社会. 法を犯した「少年」と「異常者」たち [Horrorhouse Society: “Juvenile” and “Abnormal" Criminals]. Tōkyō: Kōdansha, 2006

Serizawa, Kazuya 芹沢一也. Jidai ga tsukuru, kyōki: Seishiniryō to shakai 時代がつくる狂気. 精神医療と社会 [Insanity Constructed by an Era: Psychiatric Care and Society]. Tōkyō: Asahi Shinbunsha, 2007

Stieda, Wilhelm. "Ueber die Psychiatrie in Japan.” In Centralblatt für Nervenheilkunde und Psychiatrie, 29, 1906, pp. 514-522

Suzuki, Akihito. "The State, Family, and the Insane in Japan, 1900-1945." In The Confinement of the Insane: International Perspectives, 1800-1965, edited by Roy Porter and David Wright. Cambridge: Cambridge University Press, 2003a, pp. 193-225

Suzuki, Akihito. "A Brain Hospital in Tokyo and Its Private and Public Patients, 1926-45." In History of Psychiatry, 14/3, 2003b, pp. 337-360

Tadros, Victor. "Between Governance and Discipline: The Law and Michel Foucault." In Oxford Journal of Legal Studies, 18/1, 1998, pp. 75-103 
Takahashi, Satoru 高橋智. “Senzen no seishinbyōgaku ni okeru 'seishin-hakujaku' gainen no rironshi-kenkyū” 戦前の精神病学における「精神薄弱」概念の理論史研究 [An Enquiry Into the Theoretical History of the Notion of "Mental Weakness" in Pre-War Japanese Psychiatry]. In Tokushu-kyōikugaku-kenkyū 特殊教育学研究 [Research in Special Education], 35, 1997, pp. 33-43

Totsuka, Etsurō. "The History of Japanese Psychiatry and the Rights of Mental Patients." In Psychiatric Bulletin, 14, 1990, pp. 193-200 


\section{GLOSSARY}

$\begin{array}{ll}\text { Aoyama Nōbyōin } & \text { 青山脳病院 } \\ \text { Bakemono } & \text { 化け物 } \\ \text { Daimyo } & \text { 大名 } \\ \text { Daiun-ji } & \text { 大雲寺 }\end{array}$

$\begin{array}{ll}\text { fubyōdōjoyaku } & \text { 不平等条約 } \\ \text { Genji Monogatari } & \text { 源氏物語 }\end{array}$

$\begin{array}{ll}\text { Iwakura } & \text { 岩倉 } \\ \text { kango } & \text { 監護 } \\ \text { ki } & \text { 気 } \\ \text { ki-chigai } & \text { 気違い } \\ \text { kitsune } & \text { 狐 } \\ \text { kokutai } & \text { 国体 }\end{array}$

Kure Shūzō 呉秀三

$k y \bar{o}$

Miyake Kōichi 三宅鉱一

$\begin{array}{lc}\text { mononoke } & \text { 物の怪 } \\ \text { mono-tsuki } & \text { 物憑き } \\ \text { nihonron } & \text { 日本論 }\end{array}$

Okada Yasuo 岡田靖雄

ritsuryō 律令

Saitō Kiichi 斉藤紀一

Sakaki Hajime 棉俶

seishinbyō 精神病

seishinbyōin 精神病院

Seishinbyōin-hō 精神病院法

seishinbyōsha 精神病者

Seishinbyōsha-kango-hō 精神病者監護法 psychiatric hospital in Aoyama, Tōkyō

monster, ghost, phantom

feudal lord in pre-modern Japan

temple in Iwakura, famous for curing

mentally ill in ancient times

unequal treaties

novel by Murasaki Shikibu dating to the early 11 th century, stories about the

prince Genji

region north of Kyōto

custody

energy, spirit, mind, heart, nature, mood

madness, literally: deviant mood or

energy flux

fox, especially red fox

national polity, national essence or

identity, national or political body

(1865-1932) one of the founding fathers

of psychiatry in Japan, probably most

famous psychiatrist in the history of Japan mental abnormality

(1876-1954) Japanese psychiatrist, professor, successor to Kure Shūzō at the Imperial University of Tōkyō

demon, ghost, spectre

being possessed, a possessed person

discourse on Japan or the distinct features of the Japanese, often theorising about Japan's uniqueness and homogeneity (b. 1931) Japanese psychiatrist, wrote the first extensive sociological survey on a psychiatric hospital in Japan administrative, penal and civil code, deriving from classic Confucian Chinese law, basis of ancient East Asian law (1861-1928) Japanese politician, physician and psychiatrist, founder of the Aoyama psychiatric hospital (1857-1897) Japanese psychiatrist, first professor of psychiatry at the Imperial University of Tōkyō mental illness psychiatric hospital Mental Hospital Act of 1919 a mentally ill person Mental Patients Custody Act of 1900 


$\begin{array}{ll}\begin{array}{ll}\text { Serizawa Kazuya } \\ \text { Sōma Tomotane }\end{array} & \begin{array}{l}\text { 芹沢一也 } \\ \text { 相馬誠胤 }\end{array} \\ \text { Sōma-jiken } & \text { 相馬事件 } \\ \text { Sugita Naoki } & \text { 杉田直樹 } \\ \text { ten } & \text { 癲 } \\ \text { ten-kyō } & \text { 癲狂 } \\ \text { Tōkyō } & \text { 東京 } \\ \text { Tōkyō Teikoku Daigaku } & \text { 東京帝国大学 } \\ \text { Uraga } & \text { 浦賀 } \\ \text { Yamato } & \text { 大和 } \\ \text { Yomiuri Shimbun } & \text { 読売新聞 } \\ \text { zashikirō } & \text { 座敷牢 }\end{array}$

(b. 1968) Japanese sociologist from Kyōto (1852-1892) daimyō of the Bakumatsu era (1853-1868), descendant of the influential Sōma-clan scandal involving the illegitimate confinement of Sōma Tomotane (1887-1949) Japanese physician and psychiatrist

madness, epilepsy

insanity, madness, epilepsy capital of Japan former name of Tōkyō University subdivision of the city of Yokosuka in Kanagawa prefecture ancient name of Japan, originally an area around today's Nara prefecture Japanese newspaper cell for confinement of criminals and lunatics 